\title{
Analysing students' perceptions of two learning and evaluation modalities in the InGenio FCE Online Course and Tester
}

\author{
Antonio Martínez-Sáez ${ }^{1}$, Ana Sevilla-Pavón², \\ and Ana Gimeno-Sanz ${ }^{3}$
}

\begin{abstract}
Instructors have to make important decisions regarding the type of assessment that will finally be implemented when producing online learning materials, since this has a noticeable effect in terms of the methodology, the approach, and the attitude of all the actors involved (Goertler, 2011). This study investigates students' perception of tutor assessment and self-assessment in an online upper-intermediate level English course (described in Martínez-Sáez, 2015) and testing tool (described in Sevilla Pavón, 2013). After the implementation of these learning resources through the online authoring tool and content manager InGenio ${ }^{4}, 95$ students participated in the study conducted for the validation stages. The statistical analysis of the data gathered by means of questionnaires showed that the students highly appreciated the freedom to learn at their own pace offered by these two modalities which can contribute to autonomous progress and learning.
\end{abstract}

Keywords: attitudes, assessment, online resources, validation.

\section{Introduction}

Students' attitudes and motivation are two components which play a central role in language learning (Grzib-Schlosky, 2002; Martínez-Sáez, 2015). These features, along with learners' specific goals, interests, needs, or expectations, were deemed key to strategic objectives during the production of the InGenio learning resources,

\footnotetext{
1. Universidad Politécnica de Madrid, Madrid, Spain; antonio.martinezs@upm.es

2. Universitat de València, València, Spain; ana.m.sevilla@uv.es

3. Universitat Politècnica de València, València, Spain; agimeno@upvnet.upv.es

4. InGenio was designed and developed at Universitat Politècnica de València
}

How to cite this article: Martínez-Sáez, A., Sevilla-Pavón, A., \& Gimeno-Sanz, A. (2018). Analysing students’ perceptions of two learning and evaluation modalities in the InGenio FCE Online Course and Tester. In P. Taalas, J. Jalkanen, L. Bradley \& S. Thouësny (Eds), Future-proof CALL: language learning as exploration and encounters - short papers from EUROCALL 2018 (pp. 193-199). Research-publishing.net. https://doi.org/10.14705/rpnet.2018.26.836 
and have been the basis for the research described in this paper. The resulting courseware comprises an online course and a tester aimed at helping students track their own progress before facing any official upper-intermediate English exam - B2-level according to the Common European Framework of Reference for Languages (CEFRL).

Upon designing and developing the courseware, research was conducted on the importance of assessment within the learning process and the theoretical distinction between several pedagogical strategies in an attempt to improve the learning and evaluation method offered to the final users. The authors explored how online authoring tools and content managers, and in particular, InGenio, contribute to effectiveness and efficiency when two modalities such as self-assessment and tutor assessment are integrated into the resulting resources in order to allow students to monitor their process. One of the main advantages reported was the flexibility and adaptability provided to the students by this type of system (Sevilla-Pavón, Martínez-Sáez, \& Macario de Siqueira, 2011).

In the design and development stages, special attention was paid to the variants known as tutor assessment, i.e. an autonomous online learning process monitored by a lecturer, and self-assessment, i.e. an autonomous online learning process in which students receive previously designed automatic feedback, hints, as well as model answers (both in the written and oral sections). The first modality "leads to the development of the students' autonomy and sense of responsibility over the learning process, while enabling students to get as much help and support as they need from a human tutor in order to both complete the different tasks and attain the target level of language" (Sevilla-Pavón et al., 2011, p. 47). The second modality "enables students to conduct their own learning process and to assess their own learning achievements in an independent and autonomous way" (Sevilla-Pavón et al., 2011, p. 47). These were the two learning and evaluation methods which were finally integrated into the courseware in order to respond to the highly demanding requirements and standards of an effective self-access online course (GimenoSanz, 2009; Levy \& Stockwell, 2006).

\section{Method}

This paper addresses a specific part of the InGenio Course and Tester validation study conducted throughout two consecutive academic years (2011-12 and 2012-13). A total number of 95 undergraduate students took part in it. They had previously enrolled on the course 'Computer-Assisted English' (4.5 ECTS), an 
online subject offered at Universitat Politècnica de València. All students were granted access to the InGenio FCE Online Course \& Tester (Module 1) s $^{5}$ and were asked to complete all their contents in one semester. Therefore, all the students engaged in both tutoring assessment and self-assessment, i.e. the two learning and evaluation variants finally incorporated into the resulting courseware.

Two different questionnaires (available from Martínez-Sáez, 2015) were designed so as to monitor students' progress and perceptions of a wide variety of components before (pre-course survey) and after (post-course survey) completing the first module of the Course and Tester. Among the components measured by these surveys administered through Google Forms, the following stand out: (1) length, usefulness, and effectiveness of the theoretical and practical contents; (2) the templates provided by the online authoring tool; (3) feedback; (4) interaction between the user and the platform; and (5) the range of assessment options.

Thus, in this part of the study, the participants rated and evaluated the above-mentioned learning and assessment modalities. They also compared them with other learning scenarios in order to determine which alternative would best suit their needs and interests. In so doing, the fourth part of the pre-course survey was entitled 'Learning styles' and included two multiple-choice and two open-ended questions. As for the post-course survey, it was based on a 7-point Likert scale and included several enquiry items relating to learning and assessment modalities. These items were queried in two different sections: 'General features' and 'Student self-assessment and personal comments', comprised of four and seven questions, respectively.

Due to the significant amount of data retrieved through the two questionnaires, only the most outstanding findings relating to the aims of this paper will be included.

\section{Results and analysis}

\subsection{Pre-course survey}

In the initial questionnaire, the 95 students had to decide on the best way to learn a language; their preference went for a Face-to-Face (F2F) course in the classroom with a teacher (see Figure 1). These preferences can be compared with the results displayed in Figure 3.

5. The first module of the Course and Tester was implemented in 2011. 
Figure 1. The best way to learn a language is... (pre-course survey)

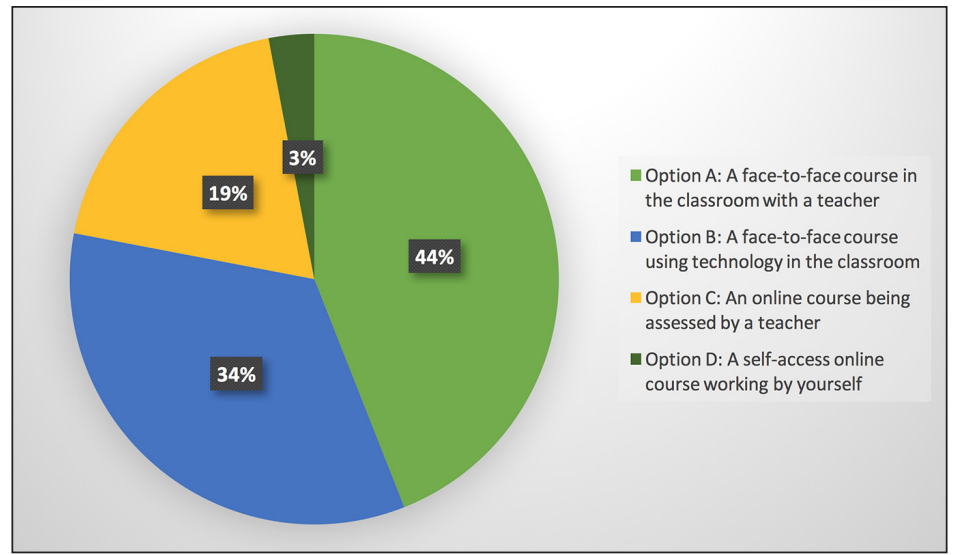

Figure 2 illustrates the participants' perceptions when asked about the most appropriate assessment modality in that particular online learning context. In the open-ended questions, a high number of students reported that flexibility is seen as an essential component when learning a language and that they highly valued feedback provision.

Figure 2. Which learning modality would you prefer?

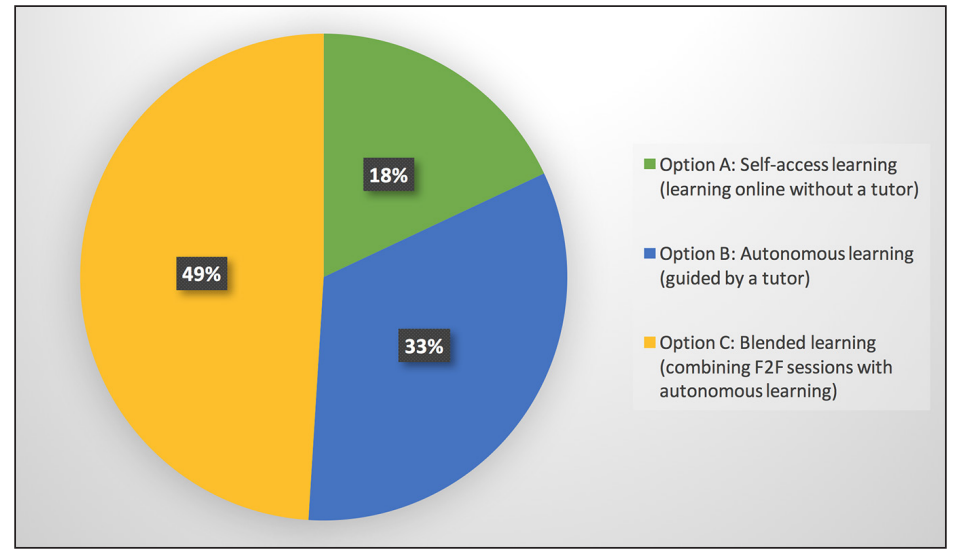

\subsection{Post-course survey}

A total number of 49 students completed all the Course and Tester contents and tasks and participated in this survey. In Section A, they rated four factors relating 
to the learning and assessment modalities. As shown in Table 1, the participants reported that "the Course and Tester encouraged autonomous / independent learning" (Item 17). A high number also emphasised how "they enjoyed having freedom to organise their time their own way" (Item 19) and "being able to selfassess their progress by accessing the assessment reports" (Item 21). Furthermore, the feedback they received was seen as very useful and relevant by most of the students.

Table 1. Section A (Likert scale)

\begin{tabular}{|l|l|l|l|l|l|l|l|}
\hline & $\mathbf{1}$ & $\mathbf{2}$ & $\mathbf{3}$ & $\mathbf{4}$ & $\mathbf{5}$ & $\mathbf{6}$ & $\mathbf{7}$ \\
\hline Item 17 & & & $6 \%$ & $12 \%$ & $33 \%$ & $39 \%$ & $10 \%$ \\
\hline Item 19 & & $2.5 \%$ & $2.5 \%$ & $16 \%$ & $12 \%$ & $20 \%$ & $47 \%$ \\
\hline Item 21 & & & $2 \%$ & $14 \%$ & $31 \%$ & $29 \%$ & $24 \%$ \\
\hline
\end{tabular}

Section $\mathrm{C}$, the third part of the post-course questionnaire, provided evidence of students' very positive attitude towards the use of technology and, in particular, to online environments after completing the Course and Tester. They also found it very easy to work autonomously.

Figure 3 illustrates that the students' general perception of the best modality to join a language course had experienced some changes when compared with the same question in the first questionnaire. The percentages of Options $\mathrm{C}$ and $\mathrm{D}$ were still very low in the final survey. However, there was an increase of $11 \%$ in the number of students who opted for Option B, which had a clear negative impact on Option A.

Figure 3. The best way to learn a language is... (post-course survey)

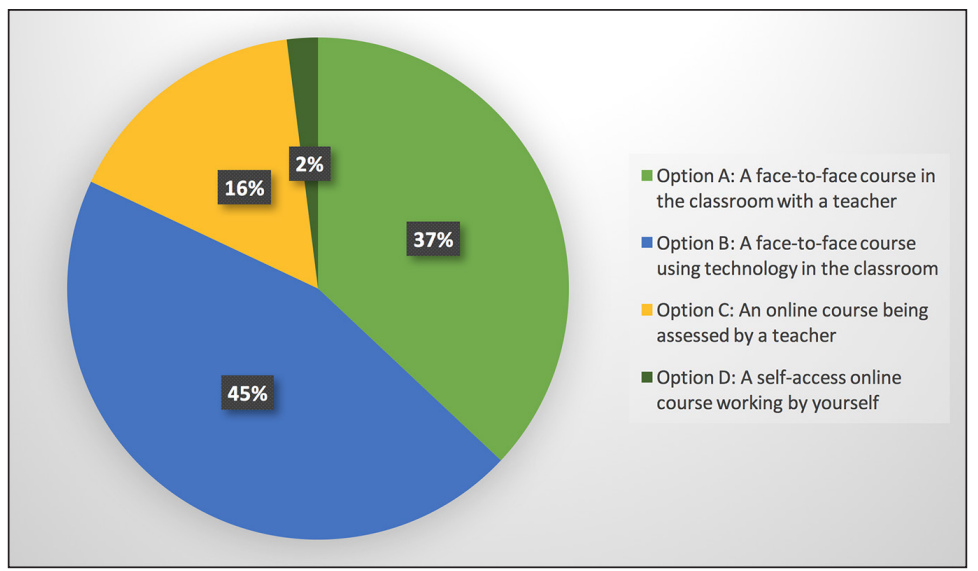




\section{Conclusions}

As seen in the previous section, students' perceptions of the courseware and most of the components were very positive. An outstanding number welcomed features such as being able to self-assess their own progress and felt comfortable working in an online environment. However, when asked about their general perception of the best modality to take a language course, a significant number of learners still reported a preference for a hypothetical blended-learning alternative combining the F2F classroom component being assisted by a lecturer or tutor with an appropriate use of the online resources provided. Even though technology, flexibility, and adaptability were seen as fundamental and motivating features, the support given by the human component was highly appreciated.

\section{Acknowledgements}

We would like to thank the Valencian Regional Government (Generalitat Valenciana).

Antonio Martínez-Sáez and Ana Sevilla-Pavón were still holders of a four-year research grant (FPI) when the data began to be collected.

\section{References}

Gimeno-Sanz, A. (2009). Online courseware design and delivery: the InGenio authoring system. In I. González-Pueyo, C. Foz Gil, M. Jaime Siso \& M. J. Luzón Marco (Eds), Teaching academic and professional English online (pp. 83-105). Peter Lang.

Goertler, S. (2011). Blended and open/online learning: adapting to a changing world of language teaching. In N. Arnold \& L. Ducate (Eds), Present and future promises of CALL: from theory and research to new directions in language learning (pp. 471-502). CALICO Publications.

Grzib-Schlosky, G. (2002). Bases cognitivas y conductuales de la motivación y emoción. Centro de Estudios Ramón Areces (CERA).

Levy, M., \& Stockwell, G. (2006). CALL dimensions: options and issues in computer-assisted language learning. Lawrence Erlbaum.

Martínez-Sáez, A. (2015). Materiales online para el aprendizaje y la evaluación del inglés: análisis, diseño, propuesta y validación de recursos. Doctoral Thesis. Universitat Politècnica de València. https://www.educacion.gob.es/teseo/irGestionarConsulta.do 
Sevilla-Pavón, A., Martínez-Sáez, A., \& Macario de Siqueira, J. (2011). Self-assessment and tutor assessment in online language learning materials: InGenio FCE Online Course and Tester. In S. Thouësny \& L. Bradley (Eds), Second language teaching and learning with technology: views of emergent researchers (pp. 45-69). Research-publishing.net. https://doi. org/10.14705/rpnet.2011.000006

Sevilla Pavón, A. (2013). Desarrollo, implementación y validación de recursos multimedia para la enseñanza y la evaluación del nivel B2 de inglés en contextos de educación superior a través del sistema InGenio. Doctoral Thesis. Universitat Politècnica de València. 


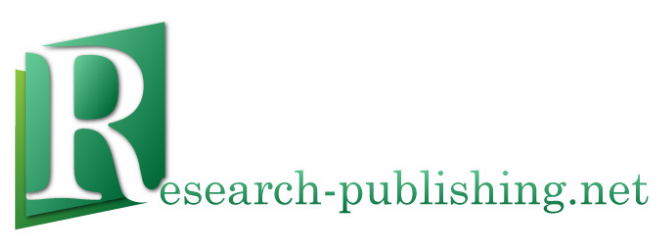

Published by Research-publishing.net, a not-for-profit association Contact: info@research-publishing.net

(C) 2018 by Editors (collective work)

(C) 2018 by Authors (individual work)

Future-proof CALL: language learning as exploration and encounters - short papers from EUROCALL 2018 Edited by Peppi Taalas, Juha Jalkanen, Linda Bradley, and Sylvie Thouësny

\section{Publication date: 2018/12/08}

Rights: the whole volume is published under the Attribution-NonCommercial-NoDerivatives International (CC BYNC-ND) licence; individual articles may have a different licence. Under the CC BY-NC-ND licence, the volume is freely available online (https://doi.org/10.14705/rpnet.2018.26.9782490057221) for anybody to read, download, copy, and redistribute provided that the author(s), editorial team, and publisher are properly cited. Commercial use and derivative works are, however, not permitted.

Disclaimer: Research-publishing.net does not take any responsibility for the content of the pages written by the authors of this book. The authors have recognised that the work described was not published before, or that it was not under consideration for publication elsewhere. While the information in this book is believed to be true and accurate on the date of its going to press, neither the editorial team nor the publisher can accept any legal responsibility for any errors or omissions. The publisher makes no warranty, expressed or implied, with respect to the material contained herein. While Researchpublishing.net is committed to publishing works of integrity, the words are the authors' alone.

Trademark notice: product or corporate names may be trademarks or registered trademarks, and are used only for identification and explanation without intent to infringe.

Copyrighted material: every effort has been made by the editorial team to trace copyright holders and to obtain their permission for the use of copyrighted material in this book. In the event of errors or omissions, please notify the publisher of any corrections that will need to be incorporated in future editions of this book.

Typeset by Research-publishing.net

Cover theme by (C) 2018 Antti Myöhänen (antti.myohanen@gmail.com)

Cover layout by (C) 2018 Raphaël Savina (raphael@savina.net)

Drawings by (C) 2018 Linda Saukko-Rauta (linda@redanredan.fi)

ISBN13: 978-2-490057-22-1 (Ebook, PDF, colour)

ISBN13: 978-2-490057-23-8 (Ebook, EPUB, colour)

ISBN13: 978-2-490057-21-4 (Paperback - Print on demand, black and white)

Print on demand technology is a high-quality, innovative and ecological printing method; with which the book is never 'out of stock' or 'out of print'.

British Library Cataloguing-in-Publication Data.

A cataloguing record for this book is available from the British Library.

Legal deposit, UK: British Library.

Legal deposit, France: Bibliothèque Nationale de France - Dépôt légal: Décembre 2018. 